\title{
The occurrence of wildcats in the southern Swiss Jura Mountains
}

\author{
Michael DÖTTERER* and Frank BERNHART
}

\begin{abstract}
Dötterer M. and Bernhart F. 1996. The occurrence of wildcats in the southern Swiss Jura Mountains. Acta Theriologica 41: 205-209.

Fourteen wildcats Felis silvestris silvestris Schreber, 1777 were trapped in winter 1993 in the southern part of the Swiss Jura Mountains as a bycatch. During the last thirty years of protection the presence of wildcats in Switzerland could be confirmed by a few dead-found individuals, but the status of the species was unknown. This is the first indication of an existing population. Even though the upper distribution limit of wildcats in central and western Europe is described at $800 \mathrm{~m}$ a.s.l., most individuals were caught in altitudes from 970 to $1200 \mathrm{~m}$. We registered a higher catching success in south exposed beech forest and in the sycamore forest, than in the northern exposed Norway spruce forest. During snowcover above $30 \mathrm{~cm}$ no wildcats were caught. The capture sites were located within distances of 200-1900 m from human settlements.
\end{abstract}

Norwegian Institute of Nature Research (NINA), Tungasletta 2, N-7005 Trondheim, Norway (MD); Dans les Crocus, CH-1453 Bullet, Switzerland (FB)

Key words: Felis silvestris, capture, distribution, habitat, Switzerland

\section{Introduction}

Since the middle ages the wildcat Felis silvestris silvestris Schreber, 1777 was exposed to extensive habitat loss and hunting pressure (Eiberle 1980) in central and western Europe. In the lowlands of Switzerland the wildcat became extinct in the 1920s, whereas in the Jura Mountains this species was common until 1930, but decreased continuously (Eiberle 1980). After its protection in 1962 to 1992 only 13 individuals in the Swiss part and 3 individuals in the French part of the Jura Mountains could be confirmed (Schauenberg 1970, Eiberle 1980, Lüps 1993, P. Lüps, pers. comm.). They were killed by cars or shot during red fox Vulpes vulpes hunt (Lüps 1993). The observations were scattered over large parts of the Jura Mountains (Lüps 1993) and could not reveal sufficient information on the status of the wildcat. In the 1970s a few individuals were reintroduced without scientific documentation (Lüps 1993). Now in 1993 we obtained the most current indication of an existing wildcat population during the fieldwork of the Swiss Lynx Project.

\footnotetext{
*Correspondence address: Norwegian Institute of Nature Research, Melgården, N-2450 Rena, Norway
} 


\section{Study area and methods}

The study area is situated in the southern part of the Swiss Jura Mountains. Forest cover is $35-40 \%$. The higest peak is on $1679 \mathrm{~m}$ a.s.l. In altitudes from $500-1200 \mathrm{~m}$ a.s.l. mixed deciduous forest dominates. In cold high valleys over $1000 \mathrm{~m}$ a.s.l. and generally above $1200 \mathrm{~m}$ there is coniferous forest with Norway spruce Picea abies and European silver-fir Abies alba. On an area of $275 \mathrm{~km}^{2}, 8$ double door box traps without bait were placed to catch lynx from 12 January to 29 April 1993. Both sides of the traps were fenced by spruce branches and little trees to canal the animal's movements. The traps were situated in altitudes between 610 and $1240 \mathrm{~m}$ a.s.l. on small trails and forest roads. The distances between the traps were $3-13 \mathrm{~km}$. The traps were placed in 3 different forest communities (Ellenberg 1986; Table 1): (1) Beech forest Luzulo silvaticae Fagetum, dominated by beech trees Fagus sylvatica, warm, dry, west and south exposed, high forest (3 traps). (2) Norway spruce forest Abieti-Fagetum, dominated by Norway spruce, cold, humid, north and east exposed, high forest (3 traps). (3) Sycamore forest Phyllitido-Aceretum, dominated by sycamore Acer pseudoplatanus, cold, humid, shrub wood, used since generations for fire wood production (2 traps).

The wildcats were not drugged but released at once after documentation by photo or video. To identify the species we used the field characteristics described by Piechocki (1990). Additionally we took into acount behaviour patterns like agression, which were different to the ones of domestic cats Felis silvestris $f$. catus caught during the catching season. Video documentations of 6 wildcats were presented at the Wildcat Symposium (held by BUND-Bavaria in Wiesenfelden, Germany, March 1993). All experts identified the animals as wildcats $F$. silvestris.

\section{Results}

Nineteen times there were cats caught. Five times animals were non-wild coloured domestic cats. Thirteen times animals had all field characteristics of wildcats. One animal was missing the black dorsal stripe from the shoulders to the beginning of the tail, but still was considered as a wildcat. The wildcats were caught in 6 of the 8 box traps with a catching success of 1 wildcat/53 days (Table 1 ).

Table 1. Trap site characteristics and number of wildcats caught in the southern Jura Mountains.

* Forest communities: 1 -Luzulo silvaticae-Fagetum, 2 -Abieti-Fagetum, 3 -Phyllitido-Aceretum.

\begin{tabular}{|c|c|c|c|c|c|c|c|c|c|}
\hline Trap & $\begin{array}{l}\text { Altitude } 1 \\
\text { (m a.s.l.) }\end{array}$ & $\begin{array}{l}\text { Exposi- } \\
\text { tion }\end{array}$ & $\begin{array}{c}\text { Forest } \\
\text { com- } \\
\text { munity* }\end{array}$ & $\begin{array}{l}\text { Distance } \\
\text { to rocks } \\
\quad(\mathrm{m})\end{array}$ & $\begin{array}{l}\text { Distance } \\
\text { to civilisa- } \\
\text { tion (m) }\end{array}$ & $\begin{array}{l}\text { Trap- } \\
\text {-days }\end{array}$ & $\begin{array}{l}\text { Wildcats } \\
\text { caught }\end{array}$ & $\begin{array}{l}\text { Indi- } \\
\text { viduals }\end{array}$ & Date of capture \\
\hline 1 & 610 & $\mathrm{NN}$ & 3 & 0 & 400 & 95 & 2 & 2 & 23 Jan, 13 Feb \\
\hline 2 & 700 & SW & 3 & 0 & 200 & 28 & 0 & 0 & - \\
\hline 3 & 970 & SE & 1 & 0 & 600 & 108 & 3 & 2 & $15 \mathrm{Jan}, 20 \mathrm{Mar}, 28 \mathrm{Mar}$ \\
\hline 4 & 1000 & $\mathrm{EE}$ & 2 & 40 & 1100 & 99 & 1 & 1 & $17 \mathrm{Mar}$ \\
\hline 5 & 1090 & SS & 1 & 300 & 1020 & 105 & 3 & 2 & $01 \mathrm{Feb}, 04 \mathrm{Apr}, 27 \mathrm{Apr}$ \\
\hline 6 & 1100 & SE & 1 & 0 & 450 & 106 & 4 & 2 & $\begin{array}{l}29 \mathrm{Jan}, 14 \mathrm{Feb}, 15 \mathrm{Feb} \text {, } \\
19 \mathrm{Apr}\end{array}$ \\
\hline 7 & 1200 & NW & 2 & 10 & 1900 & 101 & 1 & 1 & $16 \mathrm{Feb}$ \\
\hline 8 & 1240 & $\mathrm{EE}$ & 2 & 0 & 1450 & 98 & 0 & 0 & - \\
\hline Total & & & & & & 740 & 14 & 10 & \\
\hline
\end{tabular}


From photo- and video-documentations we were able to identify 10 different individuals (Table 1). The following text deals with individuals and focuses on 5 parameters, that we thought to be of importance for the ecology of wildcats.

1. Forest communities. In the Luzulo silvaticae-Fagetum 6 individuals were caught during a total of 319 trap-days ( 1 ind/53 trap-days). In the Phyllitido-Acerctum 2 inds during 123 trap-days ( $1 \mathrm{ind} / 62$ trap-days). In the Abieti-Fagetum -2 inds during 298 trap-days ( 1 ind/149 trap-days; Table 1 ).

2. Altitude. Wildcats were caught in altitudes between $610 \mathrm{~m}$ a.s.l. and $1200 \mathrm{~m}$ a.s.l. No catching occurred in the highest trap on $1240 \mathrm{~m}$ a.s.l., and in the trap on $700 \mathrm{~m}$ a.s.l. which was activated for only a short period.

3. Distance to rock. Rock was defined as a band of cliffs or a single boulder of minimum $5 \mathrm{~m}$ height and $20 \mathrm{~m}$ length. All captures occurred directly at or close to rocks $(<40 \mathrm{~m})$, except of those two individuals caught in trap no 5 . There an immense cliff in a distance of $300 \mathrm{~m}$ cannelled all animal movements to the trap placed at the end of a forest road (Table 1).

4. Distance to civilisation. The distances to human settlement (village border, used farm house) ranged from $200 \mathrm{~m}$ to $1900 \mathrm{~m}$. No wildcat was caught in the trap closest to human settlement, and in the second most distant trap (Table 1).

5. Snow cover. The whole trapping season could be divided into 3 periods: (a) during 276 trap-days without snow, 6 individuals were caught ( 1 ind/46 trap-days), (b) during the following 147 trap-days with a permanent snow cover over $30 \mathrm{~cm}$, no wildcat was caught, (c) in the final period of 317 trap-days without snow or with melting snow between 5 and $20 \mathrm{~cm}, 4$ individuals were caught (1 ind/79 trap-days).

\section{Discussion}

Hubbard et al. (1991) used DNA techniques to identify 34 wildcat hybrids with domestic cats out of 42 individuals with the described phenotypic characteristics of wildcats. This makes the use of Piechockis (1990) field characteristics for the classification of pure wildcats questionable. Of course, all animals caught might be hybrids with regard to the potential overlap of domestic and wildcat in the study area. All the box traps were located within $2 \mathrm{~km}$ of human settlement. According to Liberg (1980) this distance is inside the range of free living domestic cats. The fact that also 5 domestic cats were caught in the traps, the furtherst in a distance of $1100 \mathrm{~m}$ to human settlement, confirmed the evidence. Another hint for interbreeding was the lacking of the dorsal stripe of one wild coloured individual.

The habitat parameters connected to the location of the traps were chosen by the authors to optimize lynx catching success. Therefore, they do not reflect an independant sample, but they provide us with some additional information to existing literature on the wildcat distribution. 
Schauenberg (1981) set the upper distribution limit of the wildcat in central and western Europe at an altitude of $800 \mathrm{~m}$ a.s.l. Our catching success on up to $1200 \mathrm{~m}$ a.s.l. and the indication of two individuals on $970 \mathrm{~m}$ a.s.l. (Lüps 1993) sets the upper distribution limit much higher. One reason for it could be the warm winters during the last decade, when the scarce snow cover did not reduce roaming activity and food availability of these small predators. A strong indication for this is the catching success changing with different snow covers. In the 3 week long period with snow higher than $30 \mathrm{~cm}$ no wildcat was caught. The animals either reduced their movements or roamed to lower altitudes at the slope bottom with better conditions during that time. The distance between bottom and highest ridge of the Jura Mountains does not exceed $2 \mathrm{~km}$. Considering home range sizes found by radiotelemetry of 75 to 900 ha (Corbett 1978, Artois 1985) and average home range widths of up to $3.4 \mathrm{~km}$, a wildcat can easily occupy a home range extended over the whole slope.

The trapping results reveal more wildcat activities in southern exposed slopes with Luzulo silvaticae-Fagetum than in northern slopes with Abieti-Fagetum. Also Vogt (1985) found more signs of activity in southern exposed, warm slopes, and Heller (1987) points out the importance of southern expositions for the kitten rearing period. We suggest that the high catching success in the shrub wood Phyllitido-Aceretum was due to the good food availability in this species-rich habitat.

Since the Eurasian lynx has a preference for rocky areas (Weigl 1993), we had placed all the traps in connection with rock formations. These positions have probably favoured the catching of wildcats. Inside a closed forest roof these are the only places for sun bathing with warm and dry subsoil. They might also serve as exposed structures for scent marking, as it is found for the Eurasian lynx (Weigl 1993).

Our catching results confirm the existence of a wildcat population in the Swiss Jura Mountains. We registered an even distribution of the 6 successful catching sites on a study area of $275 \mathrm{~km}^{2}$. These sites were a minimum of $4.9 \mathrm{~km}$ apart. If we consider a maximum home range diameter of $3.4 \mathrm{~km}$ (maximum home range size 900 ha in a similar habitat - Artois 1985), we can exclude that one established individual was caught in different traps.

Has this population always existed, or did it reestablish in the last two decades? In the 1950 s only one wildcat was confirmed in the Swiss Jura Mountains. During the next decades the observations increased on two, three, and finally on six wildcats in the 1980s (Lüps 1993). This increase might be a result from the protection or from the reintroduction, but it could also be caused by the increase of traffic. A methodological bias was obvious since the presence of the Swiss Lynx Project, when team-members observed or trapped a total of 5 wild coloured cats and 5 confirmed wildcats between 1989 and 1992. From our results we can not conclude if this population endured, if there was recolonization from the French Jura, immigration from the neighbouring population in Alsace or if it was reestablished by the reintroduction in the 1970s. Only a study on the population 
genetics would help to answer this question, and would furthermore give information on the viability of the existing population.

Acknowledgements: The Swiss Lynx Project was funded in 1993 by the Federal Office of Forestry, the Swiss League for Protection of Nature, the WWF Switzerland, and the League of Animal Welfare of Switzerland and Zürich. We thank U. Breitenmoser, C. Breitenmoser-Würsten and S. Capt from the Lynx Project for collaboration. S. Baumann, M. and M. Conti, M. Liberek, D. and J. Getaz, R. Mohr and C. Stern were helpfull in the field. Technical modifications were done by M. Scholl. Finally we thank B. Zimmermann and J. Linnell for reading the manuscript.

\section{References}

Artois M. 1985. Utilisation de l'espace et du temps chez le renard (Vulpes vulpes) et le chat forestier (Felis silvestris) en Lorraine. Gibier Faune Sauvage 3: 33-57.

Corbett L. 1978. Current research on wildcats - why have they increased? Scottish Wildlife 14(3): $17-21$.

Ellenberg H. 1986. Vegetation Mitteleuropas mit den Alpen in ökologischer Sicht. 4. Auflage, Ulmer Verlag, Stuttgart: 1-989.

Eiberle K. 1980. Lehren aus der Verbreitungsgeschichte der mitteleuropäischen Wildkatze. Schweizerische Zeitschrift für Forstwesen 131: 965-986.

Heller M. 1987. Die Wildkatze (Felis s. silvestris) in Baden-Württemberg. Veröffentlichungen Naturschutz und Landschaftspflege Baden-Württemberg 62: 307-323.

Hubbard A. L., Mcorist S., Jones T. W., Boid R., Scott R. and Easterbee N. 1991. Is survival of European wildcats Felis silvestris in Britain threatened by interbreeding with domestic cats? Biological Conservation 61: 203-208.

Liberg O. 1980. Spacing patterns in a population of rural free roaming domestic cats. Oikos 35 : $336-349$.

Lüps P. 1993. Die Waldkatze: keine verwilderte Hauskatze. Berichte der St. Gallischen Naturwissenschaftlichen Gesellschaft 86: 263-275.

Piechocki R. 1990. Die Wildkatze. Die neue Brehm-Bücherei 189. A. Ziemsen Verlag, Wittenberg Lutherstadt: $1-232$.

Schauenberg P. 1970. Le chat forestier d'Europe Felis s. silvestris Schreber 1777 en Suisse. Revue suisse de Zoologie 77: 127-160.

Schauenberg P. 1981. Elements d'ecologie du chat forestier d'Europe Felis silvestris Schreber 1777. Revue Ecologie (Terre et Vie) 35: 3-36.

Vogt D. 1985. Aktuelle Verbreitung und Lebensstätten der Wildkatze (Felis silvestris silvestris Schreber, 1777) in den linksrheinischen Landesteilen von Rheinland-Pfalz und Beiträge zu ihrer Biologie. Beiträge Landespflege Rheinland-Pfalz 10: 130-165.

Weigl S. 1993. Zur Habitatnutzung des Eurasischen Luchses (Lynx lynx L.) in der Kulturlandschaft des Schweizer Jura. Diploma thesis, University of Munich: 1-68. 